\title{
Correction to: Insect pollinator dependence of shea (Vitellaria paradoxa C.F. Gaertn.) in the Guinea Savanna zone of Ghana
}

\author{
Latif Iddrisu Nasare $^{1 *}$, Peter K. Kwapong ${ }^{2}$ and Dzigbodi Adzo Doke ${ }^{3}$
}

\section{Correction to: Ecol Process \\ https://doi.org/10.1186/s13717-019-0202-8}

In the original publication of this article (Nasare et al. 2019), the ' $\mathbb{C}$ ' in Ghanaian currency symbol (GHC) was omitted in below content in the pdf version of the article. It should be 'GHC'

1. "The monetary value of insect pollination was estimated at GH 73.21 (US\$ 18.67) per bag of kernel as of August 2016".

2. 'where QAI is the quantity $(\mathrm{kg})$ of kernel attributable to insect pollination, MVI is the monetary value of insect pollination (GH), and UP is the unit price of $1 \mathrm{~kg}$ of shea kernel.'

3. 'The price of a bag of shea kernel ranged from $\mathrm{GH}$ 90.00 (US\$ 22.95) to GH 105.00 (US\$ 26.78) with an average price of GH 100.00 (US\$ 25.51).'

4. In Table 3 and Table 4

The publisher apologizes to the readers and authors for the inconvenience.

The original publication has been corrected.

\section{Author details}

'Department of Forestry and Forest Resources Management, Faculty of Natural Resources and Environment, University for Development Studies, P. O. Box TL 1882, Tamale, Ghana. ${ }^{2}$ Department of Conservation Biology and Entomology, School of Biological Sciences, College of Agriculture and Natural Sciences, University of Cape Coast, Cape Coast, Ghana. ${ }^{3}$ Department of Eco-tourism and Environmental Management, Faculty of Natural Resources and Environment, University for Development Studies, P. O. Box TL 1882, Tamale, Ghana.
Published online: 09 January 2020

\section{Reference}

Nasare et al (2019) Insect pollinator dependence of shea (Vitellaria paradoxa C.F. Gaertn.) in the Guinea Savanna zone of Ghana. Ecol Process 8:48 https://doi. org/10.1186/s13717-019-0202-8

* Correspondence: latifnasare@uds.edu.gh

The original article can be found online at https://doi.org/10.1186/s13717019-0202-8

${ }^{1}$ Department of Forestry and Forest Resources Management, Faculty of Natural Resources and Environment, University for Development Studies, P. O. Box TL 1882, Tamale, Ghana

Full list of author information is available at the end of the article 